\title{
Um papel para a revista científica no desenvolvimento da excelência académica
}

\author{
A role for the scientific journal in the development of academic \\ excellence
}

\section{J. Vasconcelos-Raposo}

Director da Revista Motricidade - Universidade de Trás-os-Montes e Alto Douro

A excelência, tal como a concebemos implica aprendizagem, transmissão e reprodução do saber. Um professor universitário só é verdadeiramente excelente quando os seus alunos reconhecidamente se demonstram melhores do que eles foram. Em contrapartida, é típico de um aluno medíocre e intelectualmente pobre $\mathrm{o}$ acto de não reconhecer o contributo que os outros deram para a sua formação.

A revista científica é, por excelência, um veículo para a transmissão e reprodução do saber, na medida que sem a sua intervenção dificilmente se desenvolvem Escolas de pensamento e, consequentemente, de conhecimento. A importância da revista e os seus propósitos mais nobres é algo que todos os professores devem valorizar nas suas práticas. Para tal ensinam os discentes a escreverem trabalhos científicos e, consequentemente, divulgá-los na forma de publicação. Neste processo, os docentes devem assumir um papel de referência, destacando a importância das nuances e detalhes que devem prevalecer na comunidade científica.

Não há lugar ao desenvolvimento da excelência sem o encorajamento para os mais novos e aprendizes serem criativos e sem a promoção daquele que é, provavelmente, o ingrediente fundamental: a liberdade de pensar. $\mathrm{O}$ actual sistema de ensino, tal como o observamos, não está vocacionado para promover a criatividade nem o direito à diferença, e que se expressa no pensamento dos discentes e docentes.
A experiência e a convivência que temos no Ensino Superior Universitário sugere-nos que, actualmente, é prática comum, na relação professor / aluno partir do princípio que os estudantes nada sabem sobre os temas abordados nas aulas. Mas esse é, talvez, um dos erros que se possa estar a cometer. Há outros equívocos que são impostos, aos professores e investigadores, a nível estrutural, pelo poder político, nomeadamente via o Ministério da Educação.

As escolas, independentemente do grau de ensino, reproduzem a crença que os docentes são possuidores de um conjunto de saberes, previamente definidos pelo Poder instituído, e cuja transmissão é apresentada como imperiosa para salvaguardar as necessidades do Sistema sócio-económico em que os professores e alunos se inserem. O Sistema Educativo opera fundamentado na proposição que todos os indivíduos devem possuir os mesmos conhecimentos básicos, de modo a partilharem as mesmas crenças, factos, valores e até atitudes relativamente aos fenómenos sócio-culturais. E, recentemente com todo o desplante se declara que a educação deve estar ao serviço do progresso científico e tecnológico, que mais não é do que ao serviço do sector industrial. Cada vez mais se esquece que o importante é fazer com que os cidadãos sejam felizes.

Somos da opinião que para, efectivamente, educarmos pessoas para a excelência, é necessário que a atitude dos docentes seja alterada. Isto é, que se reconheça que os discentes chegam até nós possuidores de um 
conhecimento social e cultural que deverá ser validado e reproduzido na escola, em função dos motivos dominantes na suas vidas pessoais.

No passado, assistimos a propostas pedagógicas que defendiam a individualização do ensino. Porém, não se fizeram quaisquer referências explícitas às alterações estruturais necessárias para a viabilização dessa alternativa educativa. Julgamos que este modelo sempre esteve votado a um sucesso relativo, na medida a que as alterações que deveriam acompanhar a implementação desta proposta nunca aconteceram.

Educar para a excelência implica mais do que a transmissão cuidada de saberes e técnicas. A excelência per se exige atitudes perante a novidade, o desconhecido e nós próprios. Por outras palavras, como docentes não poderemos pretender educar para a excelência sem, em primeiro lugar, assumirmos em pleno os elementos que caracterizam a orientação cognitiva que está na base da excelência e que, grosso modo, se alicerça na motivação intrínseca e numa orientação para a mestria.

Educar para excelência requer, forçosamente, que entendamos o ensino como uma forma de aprendizagem. A aprendizagem a que nos referimos não se limita ao enriquecimento dos nossos conhecimentos sobre determinadas áreas, através da leitura de materiais recentemente publicados e que pretendemos transmitir aos nossos alunos. Talvez o mais importante seja aceitarmos que os discentes têm algo a nos ensinar, fundamentalmente no domínio das estratégias de ensino. Para tal, devemos escutar as sugestões que estes nos possam fazer sobre a forma como abordar os tópicos que desejamos desenvolver nos nossos programas curriculares.

Frequentemente ouvimos críticas dos alunos, que nos dizem que aquilo que aprendem na escola é pouco relevante para a realidade com que se deparam no seu dia-a-dia. De facto, cada vez mais, procuramos transmitir-lhes conhecimentos especializados, mas na gestão das suas vidas como cidadãos e profissionais o que mais lhes interessa é dominarem habilidades específicas, algo que o actual sistema de ensino pouco valoriza. Este é um aspecto que requer uma grande reflexão por parte dos agentes de ensino, especialmente no que se refere à actividade de docência e os saberes a serem exigidos a estes. Acabar um curso superior e enfrentar o desemprego é, cada vez mais, a norma. Para os jovens é, cada vez mais difícil fazer planos para as suas vidas como adultos e por isso prolongam a sua adolescência. Perante isto, mais do que nunca, como professores, a promoção das condições para a realização da felicidade pessoal deverá ser uma prioridade.

Ultrapassar esta situação implica que os docentes, independentemente do grau de ensino em que intervêm, assumam uma atitude diferente perante a investigação (leia-se aprendizagem). Esta mudança requer que os docentes aceitem que os alunos, através das suas histórias pessoais, lhes dêem pistas sobre a forma como se percepcionam como aprendizes. Apenas um professor cuja orientação cognitiva seja para a mestria se sentirá confortável na situação de ser desafiado, no contexto da aula, sobre o seu saber por aqueles que $a$ priori estão ali para aprender e não para ensinar. No entanto, é nossa convicção que sem se aceitar ser simultaneamente mestre e aluno é impossível desenvolver, quer em nós próprios quer nos alunos, o gosto pela aprendizagem, que por sua vez é o único veículo para se atingir níveis de excelência.

Desenvolver o gosto pela aprendizagem é algo que transcende o papel do educador na escola. Os elementos vivos relevantes a este processo são múltiplos, e dependem do tipo de excelência em causa. Mas para os propósitos desde manuscrito destacamos a excelência académica e científica, onde a revista é um elemento essencial para o processo que conduz ao desenvolvimento da excelência.

Na realidade é através da revista científica que os mais jovens encontram o caminho a ser 
trilhado para integrarem a comunidade científica. $\mathrm{Na}$ vasta maioria dos casos, esses primeiros passos são feitos através do apoio que os seus professores lhes dão, orientandoos sobre como proceder. Mas em verdade, há professores que prestam um mau serviço à ciência, na medida em encorajam os alunos a escreverem e a submeterem trabalhos para publicação sem, no entanto, lhes dar a devida atenção na forma de supervisão relativamente aos detalhes inerentes à qualidade académica.

Enquanto editores, recebemos muitos trabalhos de alunos onde consta o nome dos professores orientadores. Porém, face à qualidade dos manuscritos submetidos, por vezes, questionamo-nos se efectivamente esses prestigiados professores e investigadores têm conhecimento da integração dos seus nomes como co-autores. Em alguns casos já tivemos a oportunidade de confirmar que sabiam, e em outros não. Em ambos os casos importa ter alguns cuidados.

O actual sistema de Ensino Superior exerce uma pressão muito grande sobre os seus professores e investigadores para publicarem, mas infelizmente é-nos dado a registar que a lógica do capitalismo selvagem (leia-se a busca pelo lucro a todo o custo) se faz repercutir nas práticas dos académicos. Assim, constatamos uma "luta desenfreada" para que os seus nomes apareçam no maior número de trabalhos publicados, e alguns conseguem. Infelizmente deixando a imagem da ambição e da falta de preocupação com a qualidade da investigação que fazem, assim como dos eventuais contributos que dão para a ciência. Mas mais, prestam um mau serviço à prática científica porque nas revistas, rejeitamos os trabalhos porque os mesmos estão mal formatados, os desenhos de pesquisa mal concebidos e as escolhas dos procedimentos estatísticos mal fundamentadas ou por vezes negligenciadas em absoluto. Os alunos recebem os comentários dos revisores e, por vezes, indignam-se porque o nome do seu professor constava como co-autor. $\mathrm{Na}$ revista Motricidade a política é contactar o mais graduado academicamente para resolver as questões em falta.

É neste actual estado de coisas que defendemos que as revistas científicas também se devem constituir como um reduto de resistência às más práticas académicas, tanto de professores, como de alunos. 